In the Eye of the Animal 
DIVINATIONS: REREADING LATE ANCIENT RELIGION

Series Editors: Daniel Boyarin, Virginia Burrus, Derek Krueger

A complete list of books in the series is available from the publisher. 


\section{In the Eye of the Animal}

Zoological Imagination in Ancient Christianity

\section{Patricia Cox Miller}

\section{$\overline{\text { PENN }}$}

UNIVERSITY OF PENNSYLVANIA PRESS PH I L A DE L P H I A 
Copyright (c) 2018 University of Pennsylvania Press

All rights reserved. Except for brief quotations used for purposes of review or scholarly citation, none of this book may be reproduced in any form by any means without written permission from the publisher.

\author{
Published by \\ University of Pennsylvania Press \\ Philadelphia, Pennsylvania I9104-4II2 \\ www.upenn.edu/pennpress \\ Printed in the United States of America on acid-free paper \\ I $355779 \begin{array}{llllll}10 & 8 & 6 & 4 & 2\end{array}$ \\ A catalogue record for this book is available \\ from the Library of Congress . \\ ISBN 978-0-8122-5035-0
}


To Wissen, Jessie, Sophie, and Ben 
When God went forth to create the world, he took his dog along. -Kato Indian creation myth 